\title{
THEORETICAL AND PRACTICAL ASPECTS OF EQUITY FINANCE OF INVESTMENT: SOURCES, FORMS, MECHANISMS, TOOLS
}

\section{Valentina N. EDRONOVA a,; Dar'ya O. MASLAKOVA ${ }^{\mathrm{b}}$}

\author{
a National Research Lobachevsky State University of Nizhny Novgorod (UNN), \\ Nizhny Novgorod, Russian Federation \\ v.n.edronova@mail.ru \\ ORCID: not available \\ ${ }^{\mathrm{b}}$ Vladimir State University named after Alexander and Nikolay Stoletovs, \\ Vladimir, Russian Federation \\ mas-dariy@yandex.ru \\ https://orcid.org/0000-0001-9340-3359 \\ - Corresponding author
}

\section{Article history: \\ Received 15 November 2018 \\ Received in revised form \\ 9 January 2019 \\ Accepted 23 January 2019 \\ Available online \\ 30 September 2019}

JEL classification: E62

Keywords: investment, financing, sources, forms, mechanisms, instruments

\begin{abstract}
Subject Technological and technical upgrade of the Russian economy, development of the digital economy require to increase investment and elaborate some theoretical and practical issues of investment more profoundly. For example, the systematization of equity financing sources, their forms, mechanisms and tools.

Objectives The research specifies the concepts of source, forms, mechanisms and tools for equity financing of investment, and suggests the classification of forms, mechanisms and tools for equity financing of investment. We assess how some forms of equity financing contribute to the development of investment financing.

Methods The research relies upon empirical and logical projections, analysis and synthesis, generalization, systems approach, methods of comparative analysis.

Results We identifies and classified forms, tools and mechanisms of equity financing of investment and propose our technique for assessing the equity financing of investment by form of such financing for periods which are not covered with official statistical data.

Conclusions and Relevance The systematization fills in some gaps in the theory of investment financing. Techniques for assessing structural components of equity financing of investment are indispensable for determining the role of certain forms in the development of investment financing. Such techniques underlie the comparison of the Russian and foreign practices and efforts. The findings can serve for further research into investment financing.
\end{abstract}

The editor-in-charge of this article was Irina M. Vechkanova

The authorized translation by Irina M. Vechkanova

Please cite this article as: Edronova V.N., Maslakova D.O. Theoretical and Practical Aspects of Equity Finance of Investment: Sources, Forms, Mechanisms, Tools. Digest Finance, 2019, vol. 24, iss. 3, pp. 244-255. https://doi.org/10.24891/df.24.3.244

In June 2017, the Russian Government agreed upon details of the Forecast of the SocioEconomic Development of the Russian Federation for 2018 and the 2019-2020

* For the source article, please refer to: Едронова В.Н., Маслакова Д.О. Теоретические и практические аспекты собственного финансирования инвестиций: источник, формы, механизмы, инструменты // Финансы и кредит. 2019. Т. 25. № 2. C. 480-496. URL: https://doi.org/10.24891/fc.25.2.480
Projected Period ${ }^{1}$. According to the Forecast, the economic growth will revitalize as soon as investing activities go up mainly due to a greater role of private business, with corporate profits 
being the main resource for recovering investing activities of entities. As forecasters presume, as budgetary capital expenditures continue dropping (by 4.1 percent a year on average), corporate equity will remain the main resource for investment in the mid-term run.

As per Article 9, Financial Sources of Capital Expenditures, of Federal Law of February 25, 1999 № 39-Ф3, On Investing Activities in the Russian Federation Through Capital Expenditures, investors use their equity and raised funds to finance capital expenditures. In the Official Statistical Methodology for Identifying Investment in Capital Stock at the federal level, which is approved with Order of November 25, 2015 № $746^{2}$ of the Russian Federal State Statistics Service, and at the regional level, as enacted with Order of September 18, 2014 № $569 \mathrm{~B}^{3}$,equity shall include available corporate profit, reserve funds, shareholders' contributions to the authorized capital for investment in capital stock, funds paid by insurance bodies to reimburse losses from accidents, natural disasters. Currently, as per Order of August 30, 2017 № 562 of the Russian State Statistics Service, On Approval of the Federal Statistical Oversight of Construction, Investment in Non-Financial Assets and Housing and Utilities ${ }^{4}$, equity used to finance investment are recognized in the same line of statistical reports (Form $\Pi-2$ (invest) - Information on Investing Activities, Form ИАП - Examination of Corporate Investing Activities) and official data of the Russian State Statistics Service on investment in equity-based financial sources. They are not broken down into their constituents (Table 1).

Official statistics itemize financial sources of capital stock. However, the limitation does not affect

\footnotetext{
${ }^{2}$ Order of the Russian Federal State Statistics Service of November 25, 2015 № 746.

URL: http://www.gks.ru/wps/wcm/connect/rosstat_main/rosstat/ru /statistics/enterprise/investment/nonfinancial/ (In Russ.)

${ }^{3}$ Order of the Russian Federal State Statistics Service of September 18, 2014 № 569.

URL: http://www.gks.ru/wps/wcm/connect/rosstat_main/rosstat/ru /statistics/enterprise/investment/nonfinancial/ (In Russ.)

${ }^{4}$ Order of the Russian Federal State Statistics Service of August 30,2017 № 562.

URL: http://www.consultant.ru/document/cons_doc_LAW_256204 (In Russ.)
}

conclusions, since investment in capital stock totaled the amount invested in non-financial assets, ranging from 97.7 up to $99.1 \%$ and shaped the general trends in the investment finance ${ }^{5}$.

Analyzing Table 1, we see that in 2005-2006 the percentage of equity-based finance grew throughout the Russian Federation and a majority of the federal districts. In 2016, it accounted for more than 50 percent of the Russian average, in the Central, Northwestern, Volga, Ural and Siberian Federal Districts. In the Southern, NorthCaucasian and Far Eastern Federal Districts, equity-based finance was about 36.9-43.5 percent ${ }^{6}[1]$.

In the Khanty-Mansi Autonomous Okrug Yugra, equity-based finance makes up 90.5 percent of total finance. It is 77.7 percent, 77.4 percent in the Tyumen Oblast and Tomsk Oblast respectively. Equity-based finance was less than 30 percent of total investment in capital stock in the Smolensk Oblast, Astrakhan Oblast, Republic of Dagestan, Republic Ingushetia, KabardinoBalkar Republic, Chechen Republic, Republic of North Ossetia - Alania, Sevastopol.

According to the Federal State Statistics Service, equity-based finance increased its share in total financial sources of investment, skyrocketing from 2.9 percent to 55.8 percent, in JanuarySeptember 2017 on average in Russia. The same federal districts kept equity-based finance as much as 50 percent of total financial sources. Equity-based finance made up 70 percent of total financial sources in such constituent entities as the Khanty-Mansi Autonomous Okrug - Yugra (89.3 percent), Nenets Autonomous Okrug (85.5 percent), Udmurt Republic (80.9 percent), Kostroma Oblast (80.1 percent), Tyumen Oblast (84.3 percent), Omsk Oblast (76 percent), Tomsk Oblast (75 percent), Irkutsk Oblast (74.8 percent),

\footnotetext{
${ }^{5}$ The mix of investment in non-financial assets in the Russian Federation. URL: http://www.gks.ru/wps/wcm/connect/rosstat_ma in/rosstat/ru/statistics/enterprise/investment/nonfinancial/\# (In Russ.)

${ }^{6}$ Veretennikova O.B., Bikmetova Z.M. [Depreciation charges as a form of equity-based finance of investment]. Izvestiya Ural'skogo gosudarstvennogo ekonomicheskogo universiteta $=$ Journal of the Ural State University of Economics, 2011, no. 6, pp. 41-44.

URL: https://cyberleninka.ru/article/n/amortizatsionnyeotchisleniya-kak-forma-sobstvennyh-istochnikov-finansirovaniyainvestitsiy (In Russ.)
} 
Komi Republic (72.2 percent), Jewish Autonomous Oblast (71.4 percent), Kemerovo Oblast (71.3 percent), Chelyabinsk Oblast (70.7 percent), Magadan Oblast (70.8 percent), Stavropol Krai (70.6 percent) ${ }^{7}$.

Equity-based finance accounted for less than 30 percent in the Tver Oblast, Novgorod Oblast, Astrakhan Oblast, Rostov-on-Don Oblast, Amur Oblast, Republic of Crimea, Republic of Dagestan, Republic of Ingushetia, Republic of North Ossetia - Alania, Altai Republic, Kabardino-Balkar Republic, Yamal-Nenets Autonomous Okrug, Sevastopol.

Equity-based finance obviously proceeds from the equity of an investor. Thus, equity-based finance should be understood as economic relations of such investor in allocating and using its funds to expand, upgrade, retrofit and master new production and services. Equity-based finance comes from the same entity (involved in investment) from the same source, i.e. funds of the entity ${ }^{8}[2]$.

Analyzing the way equity-based finance can lawfully used, we point out two forms of equitybased finance, i.e. depreciation charges and profit of the entity $[3,4]$ that conducts investment activities. As above noted, official databases on equity-based finance are showed as an amount. In the mean time, the Russian Federal State Statistics Service released the information about the mix of equity-based finance, spotlighting profits and depreciation, before $2011^{9}$.

We suppose, the existing situation can be logically explained. The way the accounting

\footnotetext{
${ }^{7}$ The mix of investment in capital stock by sources of finance throughout constituent entities of the Russian Federation in January-September 2017.

URL: http://www.gks.ru/wps/wcm/connect/rosstat_main/rosstat/ru /statistics/enterprise/investment/nonfinancial/ (In Russ.)

${ }^{8}$ Kholopova Yu.S., Lukoyanchev S.S. [Factors influencing the investment activity of AIC enterprises in Ulyanovsk Region]. Izvestiya Orenburgskogo gosudarstvennogo agrarnogo universiteta $=$ Bulletin of Orenburg State Agrarian University, 2011, no. 3, pp. 268-270.

URL: https://cyberleninka.ru/article/n/faktory-vliyayuschie-nainvestitsionnuyu-aktivnost-predpriyatiy-apk-ulyanovskoy-oblasti (In Russ.)

${ }^{9}$ Russian Statistical Yearbook - 2012. Investment in Capital Stock by Source of Finance.

URL: https://uisrussia.msu.ru/stat/Publications/Ejeg2012/Ejeg201 2_24_Ejeg2012_24_050.htm (In Russ.)
}

procedure for business and financial operations is established in an entity determines the extent to which the data are unbiased in statistical accounting. Information on profit and its use, including the purchase of new equipment, production capacity upgrade, is reported in the balance sheet, being posted to respective accounts and subaccounts, as owners and shareholders may decide $^{10}$. As for depreciation, accountants recognize only amounts charged, but not the way they are debited from corporate accounts. Accumulated depreciation has not been reported as an amount of corporate funds that the entity accumulates and earmarks for reproduction of its capital stock in liabilities of a balance sheet since 1992. In 2001, lawmakers attempted to revive the practice of carrying accumulated depreciation. In 2001, the State Duma of the Russian Federation commenced hearings of the federal bill, On Turnover of Capital Stock. However, it declined the bill in $2004^{11}$. The bill was intended to mobilize domestic resources to renew, refurbish and develop the Russian economy. Entities were supposed to open a special-purpose cash account, Depreciation Funds, which they would debit for capital expenditures and recover their capital stock $^{12}$.

Perhaps, the law was dismissed because it overlooked all details of the complex mechanism for setting the depreciation policy reconciling interests of the government (fiscal aspect), business (investment aspect) and people (pricing aspects). A reduction in depreciation charges catalyzes taxes, without adding a positive effect to investment. An increase in depreciation charges cuts fiscal revenue and pumps up prices. As M.M. Sokolov fairly notes, depreciation charges have been actively influencing the cost of products or services, taxable base of profit, fiscal revenue, investing activities of entities, i.e. depreciation

\footnotetext{
${ }^{10}$ Gordeeva G.P., Plotnikova N.G., Zlobin A.M. [Problematic aspects of using the depreciation mechanism as a source of reproduction]. Finansy $i$ kredit $=$ Finance and Credit, 2014, no. 37, pp. 23-31.

URL: https://cyberleninka.ru/article/n/problemnye-aspektymehanizma-ispolzovaniya-amortizatsionnyh-otchisleniy-vkachestve-istochnika-vosproizvodstva (In Russ.)

${ }^{11}$ Report on the draft Federal Law, On Turnover of Capital Stock. URL: http://base.garant.ru/3127834/ (In Russ.)

${ }^{12}$ On turnover of capital stock.

URL: http://docs.cntd.ru/document/901856387 (In Russ.)
} 
policies determine a scenario of national economic development ${ }^{13}$.

To analyze how profit and depreciation charges have been fluctuating since 2011, we use the extrapolation method. So, we set up a technique to assess the indicators beyond periods for which the mix of equity-based finance were reported, on the basis of publicly available data [5, 6].

The proposed technique should be performed as follows:

1) extrapolating available official data in depreciation trends as a source of investment finance for the previous years to the following years;

2) extrapolate available official statistics on profit trends as a source of investment finance for the previous years to the following years;

3) combining all the data on trends in equitybased finance within total investment on the basis of estimates.

The technique below will help to understand the dynamics of depreciation charges.

- Official statistics on depreciation underlies the assessment as a source of investment finance for the previous years (2005-2011).

- A percentage of depreciation as a source of investment finance is calculated within total depreciation charges by year of the analyzable period. Official statistics on fixed assets depreciation for the same period should be used for the comparison [7].

- Analyzing whether the metric percentage of depreciation exists or demonstrates some movements, users should compute the average pace of changes in the percentage of depreciation as a financial source in total funds accrued, if the trend is seen, or average percentage of depreciation, if the trend is nonexistent [8].

- The mean deviation and variance are computed to understand whether the mean is typical as a

\footnotetext{
${ }^{13}$ Sokolov M.M. [Evolutionary developments in depreciation policies as a special form of tax regulation of economic development]. Vse o nalogakh = All about Taxes, 2010, no. 10 . URL: https://www.lawmix.ru/bux/2601 (In Russ.)
}

general characteristic of the depreciation percentage.

- Based on the mean, depreciation is assessed as a source of investment finance for periods for which the indicator is not published.

Table 2 presents the outcome of the proposed technique.

As long as there is not an explicit trend in the percentage of depreciation as a source of investment finance, the mean percentage and variance of the percentage are calculated on the basis of actual values: $\bar{x}=55,5 \%$; $\sigma= \pm 2,86 \% ; \quad V=5,2 \%$. During 2005-2011 entities spent 55.5 percent of depreciation charged for the year on investment. The variance of the factual percentage of depreciation was about 2.86 percent on average. Such variance means that the mean is standard and can be used for further computations (Table 3).

Considering that the mean percentage of depreciation earmarked for investment in total depreciation charges remained stable within 2005-2011, depreciation charges earmarked for investment in 2012-2016 demonstrate an uprising trend since as of 2016, the value is 1.605 times as high as was in 2012 , or 0.65 percent, or RUB $1,219.8$ billion.

Using a similar technique, profit can be estimated as a source of investment finance for the period [9] for which official statistics are not released (Tables 4 and 5).

As long as the percentage of profit as a source of finance does not demonstrate any obvious tendency, we compute the mean percentage and variance of the percentage by factual data: $\bar{x}=16.6 \% ; \quad \sigma= \pm 2.9 \% ; \quad V=17.5 \%$. During 2005-2011 entities spent on average 16.6 percent of their annual profit every year. The factual percentage of profit deviated from the mean estimate in both directions by 2.9 percentage on average. The variance shows whether the mean value is standard and can be used for further computations (Table 5).

Considering that the mean percentage of profit earmarked for investment in total profit remained stable within 2005-2011, profit earmarked for 
investment in 2012-2016 increased year on year. In 2016, the indicators outgrew that of 2012 by 1.775 times, or 71.76 percentage, RUB 1,097.4billion.

Referring to official statistical data on total equity-based finance of investment and estimates of Tables 3 and 5, we can itemize the equitybased finance for the period for which such data are not published (Table 6).

Depreciation charges account for the major part of total sources of investment finance. In 2012-2016, they rose steadily from 20.6 percent in 2012 up to 28.8 percent in 2016. Profit made from 15.7 percent (2013) up to 20.6 percent (2016). The percentage of depreciation was $1.3-1.5$ times as high as that of profit.

Intended for measuring the percentage of equitybased finance of investment by type of sources beyond the periods for which official data on the composition of sources are released, the proposed technique allows not only to evaluate how much equity-based finance is included in total finance, but also compare a percentage of different types of equity-based investment in Russia and those of other countries.

Considerable reforms of depreciation practices, which the USA undertook in the second half of the 20th century, raised the percentage of depreciation in total investment, from 18 percent in 1950 up to 70 percent in $2010^{14}$. As practices of foreign countries show, accelerated depreciation is especially beneficial in terms of investment since it rapidly increases the percentage of depreciation in total financial sources of investment and recovers the wear and tear of fixed assets. The accelerated depreciation method is common for the Japanese companies that use energy-efficiency equipment. In the United Kingdom, the full cost of technological equipment can be written down in the first year of its operation, while this is done within two to three years in Sweden ${ }^{15}$ [10]. Depreciation

\footnotetext{
${ }^{14}$ Sokolov M.M. [Depreciation and how it can be used to ensure economic growth]. Ekonomist, 2014, no. 2, pp. 24-43. URL: http://elib.bsu.by/bitstream/123456789/92217/1/Подходы \%20к\%20согласованию\%20промышленной\%20политики \%20ТС\%20и\%20ЕЭП.pdf (In Russ.)

${ }^{15}$ Kyurdzhiev S.P. [Foreign practices of implementing corporate depreciation policies]. Vestnik Taganrogskogo instituta
}

accounts for 50 percent to 75 percent of total capital expenditures made in the Western countries ${ }^{16}$.

Self-finance is considered high in advanced economies, equity-based sources make 60 percent and more of total financial sources of investment projects. In the USA, United Kingdom and some other countries, companies fund their investment in capital stock with equity, which account for 70-80 percent of all financial sources ${ }^{17}$. As L.L. Igonina mentions, profit and depreciation charges make 70-80 percent of total investment finance in advanced countries ${ }^{18}$. Using equity to finance investment project is evidence of good financial health of an entity, creating some competitive advantages. Fund raising is treated as a factor undermining the business reputation. Therefore, companies utilize budgetary funds only for some period of time ${ }^{19}[10]$.

Trends in the balance of financial results (Table 7) and percentage of unprofitable entities (Table 8 ) are indicative of the Russian regions' opportunities for using their equity for investment.

After a sustainable growth in 2005-2012, corporate profits slumped in 2013-2014. In 2015-2016, the economy recovered from the

upravleniya i ekonomiki $=$ Bulletin of Taganrog Institute of Management and Economics, 2013, no. 2, pp. 15-18. URL: https://cyberleninka.ru/article/n/zarubezhnyy-opytrealizatsii-amortizatsionnoy-politiki-organizatsiy (In Russ.)

${ }^{16}$ Stepanenko D.M. Metody realizatsii gosudarstvennoi innovatsionnoi politiki $v$ zarubezhnoi praktike [Methods for implementing the national innovation policy abroad]. URL: http://docplayer.ru/55544279-Metody-realizaciigosudarstvennoy-innovacionnoy-politiki-v-zarubezhnoypraktike.html (In Russ.)

${ }^{17}$ Sultanov I.A. Finansy dlya investitsii iz nestandartnykh istochnikov [Investment finance from unusual sources].

URL: http://projectimo.ru/strategicheskoe-planirovanie/istochnikifinansirovaniya-investicij.html

${ }^{18}$ Igonina L.L., Opryshko E.L. [Modern tendencies of formation of sources of financing of the enterprises investment activity in the Russian economy]. Finansovaya analitika: teoriya i praktika $=$ Financial Analytics: Theory and Practice, 2011, no. 24. URL: https://cyberleninka.ru/article/n/sovremennye-tendentsiiformirovaniya-istochnikov-finansirovaniya-investitsionnoydeyatelnosti-predpriyatiy-v-rossiyskoy-ekonomik (In Russ.)

${ }^{19}$ Kyurdzhiev S.P. [Foreign practices of implementing corporate depreciation policies]. Vestnik Taganrogskogo instituta upravleniya $\mathrm{i}$ ekonomiki $=$ Bulletin of Taganrog Institute of Management and Economics, 2013, no. 2, pp. 15-18. URL: https://cyberleninka.ru/article/n/zarubezhnyy-opytrealizatsii-amortizatsionnoy-politiki-organizatsiy (In Russ.) 
general downturn due to a drop in oil prices and other external factors. In 2016, total profit of the Russian entities was twice as high as that in 2010 and 1.6 times as high as that in 2012 preceding the economic downturn. Growth rates were 1.9, 1.6, 4.3, 3, 3.8 in the Central Federal District, Northwestern Federal District, Volga Federal District, Siberian Federal District and Ural Federal District, Far Eastern Federal District, North Caucasian Federal District, and Southern Federal District respectively. As compared with 2012, some federal districts significantly outperformed the mean indicator for Russia, reaching 2.9, 2.3, 2.1, 1.9 in the Far Eastern Federal District, Southern Federal District, Northwestern Federal District and Siberian Federal District respectively.

According to the Russian Federal State Statistics Service, the balanced financial result in actual values year-on-year increased by 16.8 percent in January-November $2017^{20}$. The given data signify the high potential of financial resources of investment and their growth [11].

The way the percentage of unprofitable entities changes reinforces our previous conclusions on a growth in the potential of financial resources for investment. The number of unprofitable entities reduced in 2016 against 2010 by 0.4 percent nationwide, 1.4 percent in the Central Federal District, 1.7 percent in the Northwestern Federal District, and 0.5 percent in the Far Eastern Federal District. In the mean time, the growing number of unprofitable entities in some federal districts curbs an increase in investment resources. The North Caucasian Federal District recorded the highest growth of 5.7 percent in unprofitable entities. The growth rates were 1.6 percent, 1.4 percent, 1.7 percent, 1.3 percent and 0.2 percent in the Siberian Federal District, Volga Federal District, Southern Federal District and Ural Federal District respectively. Unprofitable entities continued to fall in numbers in JanuaryNovember 2017, reaching 28.2 percent against 29.5 percent in $2016^{21}$.

\footnotetext{
${ }^{20}$ To corporate financial results in January-November 2017. URL: http://www.gks.ru/wps/wcm/connect/rosstat_main/rosstat/ru /statistics/finance/\# (In Russ.)

${ }^{21}$ Ibid.
}

Each form of equity-based finance is germane to certain mechanisms, i.e. schemes for generating and utilizing equity intended for investment. Depreciation charges are accounted for in accordance with the Accounting Regulation Accounting for Fixed Assets (PBU 6/01) as approved by Order of March 30, 2001 № 26H of the Russian Ministry of Finance. As per the above Accounting Regulation, there are four mechanisms (methods) for accruing depreciation, i.e. straight-line method, declining method, unitof-production method, sum of years' digits method. Although not being prescribed by PBU $6 / 01$, another method is in use, i.e. the accelerated depreciation method [12, 13]. Accounting policies provide for a set of tools which can be used to charge depreciation. Such accounting policies are formulated in accordance with Federal Law of December 6, 2011 № 402-Ф3 On Accounting, Regulation on Accounting and Financial Reporting in the Russian Federation that is enacted by Order of October 6, 2008 № 106H of the Russian Ministry of Finance. As per regulatory documents, accounting policies should stipulate groups of items subject to depreciation, rules for their appraisal, time and method for charging depreciation, depreciation recognition rules in accounting books.

The accelerated depreciation rules are set forth in Article 259 of the Tax Code of the Russian Federation. As per the rules, accelerated depreciation is charged on fixed assets held on lease, handled in aggressive environments or passing faster turnovers. Having higher energy efficiency, used for R\&D.

Rules for distributing and utilizing profits are established in corporate articles of association and profit sharing plan approved by the CEO. There are two investment mechanisms in Russia with respect to profit, i.e. a resolution of owners (founders, shareholders) on the use of net profit for investment purposes or the use of investment allowance for income profit (investment deduction) $[14,15]$.

In the first case, amounts of profit to be allocated for certain purposes are determined at the end of the reporting year and approved by the resolution of the meeting of shareholders or founders. Production development expenditures include 
costs for research and development, design, construction, technological work, upgrade of technology and production process, re-equipment, retrofitting and refurbishment, expansion of enterprises ${ }^{22}$.

Entities were allowed to exercise their investment incentives for income tax after the adoption of Federal Law of November 27, 2017 № 335-Ф3, On Amendments to Part 1 and Part II of the Tax Code of the Russian Federation and Some Regulatory Acts of the Russian Federation. Such incentives are permitted in constituent entities of the Russian Federation which independently decide on classes of fixed assets and taxpayers, which are eligible to such an investment incentives, and the amount of the incentive for the regional part of income tax. Income tax are reduced by the amount of expenditures on the purchase of new fixed assets or refurbishment, upgrade, retrofit, final construction of the existing ones, which are included into three to seven depreciation groups (building, machines, motor vehicles, equipment with the useful life ranging from three to 20 years) [16-18].

An economic actor conducting investing activities independently chooses between ordinary depreciation and investment deduction, since it will not be allowed to recognize expenditures on the purchase of fixed assets through depreciation given it prefers the investment deduction. It is permitted to deduct about 90 and 10 percent of investment cost from the regional part and federal part of income tax respectively. However, the regional part of income tax shall not be less than 5 percent of pre-deduction taxable base.
The Republic of Karelia is one of the pioneering regions that enjoyed its eligibility to choose the investment deduction. As per Law of April 4, 2018 № 2225-3PK, On Amendments to the Law of the Republic of Karelia on Taxes (Tax Rates) in the Republic of Karelia $^{23}$, the investment incentive is applicable to investors that contribute their fund to the production of nutritional supplements or pharmaceuticals and materials used for health care purposes. As set forth in the law, the rate of 8.5 percent shall be applied to assess the limit of the investment incentive.

Fig. 1 depicts the system of forms, mechanisms and tools of equity-based finance of investment.

Based on the proposed classification, it is possible to determine forms of equity-based finance, assign financing mechanisms and tools to each form, differentiate the forms, mechanisms and tools. New forms, mechanisms and tools of finance can be added to the classification [19].

Analyzing the legislative and regulatory framework, specifying such concepts as source, forms, mechanisms, tools of equity-based finance of investment, reviewing the existing practices of finance recognition, we classify not only equity funds and underline their distinctions, but also forge techniques for estimate the finance proceeding from depreciation and profit. Such information is missing in official statistics, albeit being needed to make a more accurate evaluation of investment resources and find options for expanding them. Theoretical provisions and findings can be used to unfold the theory and practice of investment finance.

\footnotetext{
${ }^{22}$ Elantsev S.V. [Comparative analysis of mechanisms implied by profit sharing methods in foreign and Russian corporations]. Vestnik Chelyabinskogo gosudarstvennogo universiteta $=$ Bulletin of Chelyabinsk State University, 2012, no. 10, pp. 112-116. URL: https://cyberleninka.ru/article/n/sravnitelnyy-analizmehanizmov-metodov-raspredeleniya-pribyli-zarubezhnyh-irossiyskih-korporatsiy (In Russ.)
}

\footnotetext{
${ }^{23}$ Law of the Republic of Karelia of April 4, 2018 № 2225-3PK, On Amendments to the Law of the Republic of Karelia on Taxes (Tax Rates) in the Republic of Karelia. URL: http://www.consultant.ru/regbase/cgi/online.cgi? req=doc;base $=$ RLAW904; $=55337 \# 05063909769917168$
} 
Table 1

Percentage of equity-based finance of capital stock in total sources by federal district, 2005-2016

\begin{tabular}{lllllllll}
\hline Federal District & $\mathbf{2 0 0 5}$ & $\mathbf{2 0 1 0}$ & $\mathbf{2 0 1 1}$ & $\mathbf{2 0 1 2}$ & $\mathbf{2 0 1 3}$ & $\mathbf{2 0 1 4}$ & $\mathbf{2 0 1 5}$ & $\mathbf{2 0 1 6}$ \\
\hline Central & 38.2 & 39.4 & 42 & 46.9 & 44.1 & 44.6 & 47.8 & 52 \\
\hline Northwestern & 42.9 & 28.9 & 30.2 & 22.4 & 40.6 & 43.6 & 48.2 & 50.6 \\
\hline Southern & 47.6 & 33.5 & 44.5 & 43.9 & 34.7 & 32.5 & 34.8 & 38.5 \\
\hline North Caucasian & 22.4 & 21.8 & 27.4 & 26.1 & 28.7 & 30.8 & 38 & 36.9 \\
\hline Volga & 49.9 & 46.3 & 47.8 & 48.6 & 50.4 & 52.9 & 57.7 & 60.8 \\
\hline Ural & 55.3 & 53.9 & 53.3 & 52.4 & 52.9 & 52.1 & 58 & 53.5 \\
\hline Siberian & 55.3 & 52.1 & 48.9 & 51.6 & 52.2 & 46.5 & 52.3 & 54.7 \\
\hline Far Eastern & 24.3 & 28.1 & 23.1 & 29.8 & 35.8 & 40.1 & 43.6 & 43.5 \\
\hline Russian Federation & $\mathbf{4 4 . 5}$ & $\mathbf{4 1}$ & $\mathbf{4 1 . 9}$ & $\mathbf{4 4 . 5}$ & $\mathbf{4 5 . 2}$ & $\mathbf{4 5 . 7}$ & $\mathbf{5 0 . 2}$ & $\mathbf{5 1 . 8}$ \\
\hline
\end{tabular}

Source: Authoring based on Regiony Rossii. Sotsial'no-ekonomicheskie pokazateli 2017 [Regions of Russia. SocioEconomic Indicators 2017]. Moscow, Russian Federal State Statistics Service Publ., 2017, 1402 p.

URL: http://www.gks.ru/bgd/regl/b17_14p/Main.htm (In Russ.)

Table 2

Percentage of depreciation as a financial source of investment in total depreciation charged in 2005-2011

\begin{tabular}{llllllll}
\hline Indicators & $\mathbf{2 0 0 5}$ & $\mathbf{2 0 0 6}$ & $\mathbf{2 0 0 7}$ & $\mathbf{2 0 0 8}$ & $\mathbf{2 0 0 9}$ & $\mathbf{2 0 1 0}$ & $\mathbf{2 0 1 1}$ \\
\hline $\begin{array}{l}\text { Depreciation as part of equity-based } \\
\text { finance of investment, billion RUB }\end{array}$ & 605.5 & 729.6 & 920 & $1,161.3$ & $1,101.4$ & 1,359 & $1,713.8$ \\
\hline Depreciation charged, billion RUB & $1,042.6$ & $1,270.3$ & 1,542 & $1,907.1$ & $2,348.6$ & $2,668.8$ & $3,148.3$ \\
\hline $\begin{array}{l}\text { Percentage of depreciation as a source of } \\
\text { investment finance in total depreciation } \\
\text { charged }\end{array}$ & 58.1 & 57.4 & 59.7 & 60.9 & 46.9 & 50.9 & 54.4 \\
\hline
\end{tabular}

Note. Percentage of depreciation is calculated on the basis of official statistics.

Source: Authoring

Table 3

The volume of depreciation as a source of investment finance in 2012-2016, billion RUB

\begin{tabular}{lccccc}
\hline Indicator & $\mathbf{2 0 1 2}$ & $\mathbf{2 0 1 3}$ & $\mathbf{2 0 1 4}$ & $\mathbf{2 0 1 5}$ & $\mathbf{2 0 1 6}$ \\
\hline Depreciation charged & $3,665.3$ & $4,179.5$ & $4,751.9$ & $5,297.7$ & 5,863 \\
\hline $\begin{array}{l}\text { Depreciation as part of equity-based } \\
\text { finance of investment }\end{array}$ & $2,034.2$ & $2,319.6$ & $2,637.3$ & $2,940.2$ & 3,254 \\
\hline
\end{tabular}

Source: Authoring

\section{Table 4}

Percentage of profit as a source of investment finance in total profit, 2005-2011

\begin{tabular}{lccccccc}
\hline Indicator & $\mathbf{2 0 0 5}$ & $\mathbf{2 0 0 6}$ & $\mathbf{2 0 0 7}$ & $\mathbf{2 0 0 8}$ & $\mathbf{2 0 0 9}$ & $\mathbf{2 0 1 0}$ & $\mathbf{2 0 1 1}$ \\
\hline $\begin{array}{l}\text { Profit as part of equity-based finance of } \\
\text { investment, billion RUB }\end{array}$ & 587.3 & 759.6 & $1,010.1$ & $1,235.4$ & 963.7 & $1,130.7$ & $1,507.9$ \\
\hline Total profit, billion RUB & 3,674 & 6,085 & 6,412 & 5,354 & 5,822 & 7,355 & 8,794 \\
\hline $\begin{array}{l}\text { Percentage of profit as a source of } \\
\text { investment finance in total profit }\end{array}$ & 16 & 12.5 & 15.7 & 23 & 16.5 & 15.4 & 17.1 \\
\hline
\end{tabular}

Source: Authoring 
Table 5

Profit as a source of investment finance, 2012-2016, billion RUB

\begin{tabular}{|c|c|c|c|c|c|}
\hline Indicator & 2012 & 2013 & 2014 & 2015 & 2016 \\
\hline Total profit & 9,213 & 9,519 & 10,465 & 12,654 & 15,823 \\
\hline $\begin{array}{l}\text { Profit as part of equity-based sources of investment } \\
\text { finance }\end{array}$ & $1,529.3$ & $1,580.1$ & $1,737.2$ & $2,100.5$ & $2,626.7$ \\
\hline
\end{tabular}

Source: Authoring

Table 6

Percentage of equity-based sources of finance in total investment finance by source of finance, 2012-2016

\begin{tabular}{llllll}
\hline Indicator & $\mathbf{2 0 1 2}$ & $\mathbf{2 0 1 3}$ & $\mathbf{2 0 1 4}$ & $\mathbf{2 0 1 5}$ & $\mathbf{2 0 1 6}$ \\
\hline Investment in capital stock, billion RUB & $9,595.7$ & $10,065.7$ & $10,379.6$ & $10,496.3$ & $11,282.5$ \\
\hline Investment in capital stock, \% & 100 & 100 & 100 & 100 & 100 \\
\hline Equity, billion RUB & $4,274.6$ & $4,549.9$ & $4,742.3$ & $5,271.1$ & $5,750.7$ \\
\hline Equity, \% & 44.5 & 45.2 & 45.7 & 50,2 & 51 \\
\hline Profit, billion RUB & $1,529.3$ & $1,580.1$ & $1,737.2$ & $2,100.5$ & $2,626.7$ \\
\hline Profit, \% & 15.9 & 15.7 & 16.7 & 20 & 20,6 \\
\hline Depreciation, billion RUB & $2,034.2$ & $2,319.6$ & $2,637.3$ & $2,940.2$ & 3,254 \\
\hline Depreciation, \% & 20.6 & 23 & 25.4 & 28 & 28.8 \\
\hline Ratio of depreciation and profit & 1.3 & 1,5 & 1.5 & 1.4 & 1.4 \\
\hline Other sources, \% & 8 & 6.5 & 3.6 & 2.2 & 1.6 \\
\hline
\end{tabular}

Source: Authoring

Table 7

Balanced financial results of corporate performance, 2005-2016, trillion RUB

\begin{tabular}{lllllllll}
\hline Federal District & $\mathbf{2 0 0 5}$ & $\mathbf{2 0 1 0}$ & $\mathbf{2 0 1 1}$ & $\mathbf{2 0 1 2}$ & $\mathbf{2 0 1 3}$ & $\mathbf{2 0 1 4}$ & $\mathbf{2 0 1 5}$ & $\mathbf{2 0 1 6}$ \\
\hline Central Federal District & 1.44 & 3.1 & 3.19 & 3.65 & 2.9 & 1.66 & 2.9 & 5.85 \\
\hline Northwestern Federal Districts & 0.24 & 0.58 & 0.75 & 0.75 & 0.75 & 0.31 & 0.83 & 1.6 \\
\hline Southern Federal District & 0.06 & 0.16 & 0.17 & 0.27 & 0.16 & $(0.08)$ & 0.2 & 0.61 \\
\hline $\begin{array}{l}\text { North Caucasian Federal } \\
\text { District }\end{array}$ & 0.01 & 0.01 & 0.01 & $(0.01)$ & 0 & $(0.01)$ & 0.01 & 0.03 \\
\hline Volga Federal District & 0.43 & 0.71 & 0.84 & 1.05 & 0.94 & 0.79 & 1.09 & 1.34 \\
\hline Ural Federal District & 0.69 & 0.99 & 1.31 & 1.3 & 1.55 & 1.4 & 1.67 & 1.59 \\
\hline Siberian Federal District & 0.29 & 0.65 & 0.72 & 0.63 & 0.45 & 0.32 & 0.67 & 1.22 \\
\hline Far Eastern Federal District & 0.07 & 0.13 & 0.15 & 0.19 & 0.11 & $(0.04)$ & 0.13 & 0.56 \\
\hline Russian Federation & $\mathbf{3 . 2 3}$ & $\mathbf{6 . 3 3}$ & $\mathbf{7 . 1 4}$ & $\mathbf{7 . 8 3}$ & $\mathbf{6 . 8 6}$ & $\mathbf{4 . 3 5}$ & $\mathbf{7 . 5}$ & $\mathbf{1 2 . 8}$ \\
\hline
\end{tabular}

Source: Authoring based on Regiony Rossii. Sotsial'no-ekonomicheskie pokazateli 2017 [Regions of Russia. SocioEconomic Indicators 2017]. Moscow, Rosstat Publ., 2017, 1402 p. URL: http://www.gks.ru/bgd/regl/b17_14p/Main.htm (In Russ.) 
Table 8

Percentage of unprofitable entities in 2005-2016

\begin{tabular}{lllllllll}
\hline Federal District & $\mathbf{2 0 0 5}$ & $\mathbf{2 0 1 0}$ & $\mathbf{2 0 1 1}$ & $\mathbf{2 0 1 2}$ & $\mathbf{2 0 1 3}$ & $\mathbf{2 0 1 4}$ & $\mathbf{2 0 1 5}$ & $\mathbf{2 0 1 6}$ \\
\hline Central Federal District & 35.7 & 30.2 & 30.3 & 29.6 & 31.5 & 33.8 & 32.9 & 28.8 \\
\hline Northwestern Federal District & 32.4 & 30.7 & 32.3 & 30.7 & 32.6 & 34.4 & 33 & 29 \\
\hline Southern Federal District & 30.8 & 29 & 27.7 & 27.4 & 31 & 32.5 & 33.5 & 30.7 \\
\hline $\begin{array}{l}\text { North Caucasian Federal } \\
\text { District }\end{array}$ & 40 & 33.8 & 32.3 & 33.7 & 31.8 & 32.2 & 30.1 & 28.1 \\
\hline Volga Federal District & 37.2 & 28.3 & 28.5 & 26.2 & 28.3 & 29.6 & 30.6 & 29.7 \\
\hline Ural Federal District & 36.9 & 30.3 & 31.1 & 28.6 & 30.9 & 32.4 & 31.9 & 30.5 \\
\hline Siberian Federal District & 40.2 & 29.4 & 28.7 & 29.3 & 30.4 & 32.4 & 32.6 & 31 \\
\hline Far Eastern Federal District & 41.6 & $\mathbf{3 2 . 8}$ & $\mathbf{3 2 . 9}$ & 31.3 & 34.7 & 37.9 & 36.2 & 32.3 \\
\hline Russian Federation & $\mathbf{3 6 . 4}$ & $\mathbf{2 9 . 9}$ & $\mathbf{3 0}$ & $\mathbf{2 9 . 1}$ & $\mathbf{3 1}$ & $\mathbf{3 3}$ & $\mathbf{3 2 . 6}$ & $\mathbf{2 9 . 5}$ \\
\hline
\end{tabular}

Source: Authoring based on Regiony Rossii. Sotsial'no-ekonomicheskie pokazateli 2017 [Regions of Russia. SocioEconomic Indicators 2017]. Moscow, Rosstat Publ., 2017, 1402 p. URL: http://www.gks.ru/bgd/regl/b17_14p/Main.htm (In Russ.)

Figure 1

Forms, mechanisms and instruments of equity-based finance of investment

\begin{tabular}{|c|c|c|c|}
\hline Sources & Forms of Finance & Mechanisms & Tools \\
\hline \multirow{7}{*}{$\begin{array}{l}\text { Funds of an economic actor } \\
\text { conducting investing } \\
\text { activities }\end{array}$} & \multirow[t]{5}{*}{ Depreciation } & Straight-line method & \multirow[t]{5}{*}{ Accounting policies } \\
\hline & & Declining method & \\
\hline & & Unit-of-production method & \\
\hline & & $\begin{array}{l}\text { Sum-of-the-Years'-Digits } \\
\text { method }\end{array}$ & \\
\hline & & $\begin{array}{l}\text { Accelerated depreciation } \\
\text { method }\end{array}$ & \\
\hline & \multirow[t]{2}{*}{ Profit } & Joint decision on investment & $\begin{array}{l}\text { Resolution of founders } \\
\text { or shareholders }\end{array}$ \\
\hline & & $\begin{array}{l}\text { Investment incentive for } \\
\text { income tax }\end{array}$ & $\begin{array}{l}\text { Law on taxes in the } \\
\text { constituent entity } \\
\text { of the Russian Federation }\end{array}$ \\
\hline
\end{tabular}

Source: Authoring

\section{References}

1. Chernov I.S. [Analysis of advantages and disadvantages of own sources of financing of investment activity]. Finansovaya analitika: problemy i resheniya $=$ Financial Analytics: Science and Experience, 2012, vol. 5, iss. 32, pp. 26-33. URL: https://cyberleninka.ru/article/n/analizpreimuschestv-i-nedostatkov-sobstvennyh-istochnikov-finansirovaniya-investitsionnoydeyatelnosti (In Russ.)

2. Nedospasova O.P. [Evaluation of the effectiveness of various sources of investment financing]. Problemy sovremennoi ekonomiki = Problems of Modern Economics, 2011, no. 3, pp. 165-167. URL: https://cyberleninka.ru/article/n/otsenka-effektivnosti-razlichnyh-istochnikovfinansirovaniya-investitsiy (In Russ.)

3. Saadzhan V.A. Depreciation Policy of the Enterprises: Accounting of Factors in Case of the Method Choice. Економіка: Реаліi Часу, 2016, no. 4, pp. 69-77.

URL: https://cyberleninka.ru/article/n/depreciation-policy-of-the-enterprises-accounting-offactors-in-case-of-the-method-choice 
4. Ben-Shahar D., Margalioth Y., Sulganik E. The Straight-Line Depreciation is Wanted, Dead or Alive. The Journal of Real Estate Research, 2009, vol. 31, no. 3, pp. 351-370.

URL: http://pages.jh.edu/jrer/papers/abstract/past/av31n03/vol31n03_05.htm

5. Utkin B.E. [Directions of improving the depreciation policy in the Russian Federation]. Gosudarstvennoe upravlenie. Elektronnyi vestnik, 2014, no. 47, pp. 283-298. (In Russ.) URL: https://cyberleninka.ru/article/n/napravleniya-sovershenstvovaniya-amortizatsionnoypolitiki-v-rossiyskoy-federatsii

6. Новікова Н.М. Формування амортизаційної політики підприємства. Вісник Маріупольського державного університету. Сер.: Економіка, 2015, no. 9, pp. 75-81.

URL: https://cyberleninka.ru/article/n/formirovanie-amortizatsionnoy-politiki-predpriyatiya

7. Afanas'ev S.A. [Depreciation as an internal source of investment for renewal of fixed assets]. Molodoi uchenyi = Young Scientist, 2014, no. 4.2, pp. 13-15.

URL: https://moluch.ru/archive/63/10154 (In Russ.)

8. Chatterjee A., Dix-Carneiro R., Vichyanond J. Multi-Product Firms and Exchange Rate Fluctuations. American Economic Journal: Economic Policy, 2013, vol. 5, no. 2, pp. 77-110. URL: https://doi.org/10.1257/pol.5.2.77

9. Sharikova I.V., Sharikov A.V. [Efficiency of investment in non-operating assets]. Regional'naya ekonomika: teoriya i praktika = Regional Economics: Theory and Practice, 2014, vol. 12, iss. 15, pp. 7-19. URL: https://cyberleninka.ru/article/n/effektivnost-investitsiy-vo-vneoborotnye-aktivy (In Russ.)

10. Ponomareva N.V. [The amortization policy of enterprises in the European Union]. Bukhgalter i zakon = Accountant and Law, 2017, no. 1, pp. 25-37.

URL: https://cyberleninka.ru/article/n/amortizatsionnaya-politika-predpriyatiy-v-evropeyskomsoyuze-1 (In Russ.)

11. Kovalev V.I. [Methodology for assessing the impact of depreciation policy on the financial position of the organization]. Vestnik Sibirskogo instituta biznesa i informatsionnykh tekhnologii $=$ Herald of SIBIT, 2017, no. 2, pp. 17-25. URL: https://cyberleninka.ru/article/n/metodologiyaotsenki-vliyaniya-amortizatsionnoy-politiki-na-finansovoe-polozhenie-organizatsii (In Russ.)

12. Krupina N.N., Bartkova N.N. [Directions of restructuring of the accounting system of depreciation of fixed assets]. Vse dlya bukhgaltera = All for Accountant, 2010, no. 11, pp. 15-21.

URL: https://cyberleninka.ru/article/n/napravleniya-restrukturizatsii-uchetnoy-sistemyamortizatsii-osnovnyh-sredstv (In Russ.)

13. Avramenko E.S., Vlasov S.V., Luk'yanov S.A., Temkina I.M. [Investment policy of the region in the context of budgetary constraints and economic sanctions]. Ekonomika regiona $=$ Economy of Region, 2015, no. 1, pp. 213-223. URL: https://cyberleninka.ru/article/n/investitsionnaya-politikaregiona-v-usloviyah-byudzhetnyh-ogranicheniy-i-ekonomicheskih-sanktsiy (In Russ.)

14. Dadashev A.Z. [Formation of a tax mechanism for stimulating investment in fixed assets]. Ekonomicheskii analiz: teoriya i praktika = Economic Analysis: Theory and Practice, 2008, no. 4, pp. 10-21. URL: https://cyberleninka.ru/article/n/formirovanie-nalogovogo-mehanizmastimulirovaniya-investitsiy-v-osnovnoy-kapital-2 (In Russ.)

15. Shelyutto M.L. [Nonprofit organizations: theoretical and practical problems (Review of the 3rd Annual scientific readings in memory of Professor S.N. Bratus')]. Zhurnal rossiiskogo prava = Journal of Russian Law, 2009, no. 1, pp. 147-151. (In Russ.)

URL: https://cyberleninka.ru/article/n/nekommercheskie-organizatsii-teoreticheskie-iprakticheskie-problemy-obzor-iii-ezhegodnyh-nauchnyh-chteniy-pamyati-professora-s-n 
16. Balandina A.S. [Analysis of the application of tax benefits for the income tax in the Russian Federation]. Vestnik Tomskogo gosudarstvennogo universiteta. Ekonomika = Tomsk State University Journal of Economics, 2013, no. 1, pp. 82-88.

URL: https://cyberleninka.ru/article/n/analiz-primeneniya-nalogovyh-lgot-po-nalogu-na-pribyl-vrossiyskoy-federatsii (In Russ.)

17. Savina O.N., Zhazhin M.A. [Tax benefits for corporate profit tax: Actual issues of optimization]. Bukhgalter i zakon = Accountant and Law, 2014, no. 4, pp. 30-37.

URL: https://cyberleninka.ru/article/n/nalogovye-lgoty-po-nalogu-na-pribyl-organizatsiyaktualnye-voprosy-optimizatsii-1 (In Russ.)

18. Dreval' L.N., Sergeev S.A. [About some problems of resident taxation in special economic zones of the Russian Federation]. Sovremennaya nauka = Modern Science, 2016, no. 1, pp. 26-30.

URL: https://cyberleninka.ru/article/n/o-nekotoryh-problemah-nalogooblozheniya-rezidentov-vosobyh-ekonomicheskih-zonah-rossiyskoy-federatsii (In Russ.)

19. Glaz'ev S.Yu., Fetisov G.G. [About the strategy of sustainable development of the Russian economy]. Ekonomicheskie i sotsial'nye peremeny: fakty, tendentsii, prognoz $=$ Economic and Social Changes: Facts, Trends, Forecast, 2013, no. 1, pp. 23-35.

URL: https://cyberleninka.ru/article/n/o-strategii-ustoychivogo-razvitiya-ekonomiki-rossii (In Russ.)

\section{Conflict-of-interest notification}

We, the authors of this article, bindingly and explicitly declare of the partial and total lack of actual or potential conflict of interest with any other third party whatsoever, which may arise as a result of the publication of this article. This statement relates to the study, data collection and interpretation, writing and preparation of the article, and the decision to submit the manuscript for publication. 